\title{
Pemanfaatan Potensi Desa Berbasis Bioekonomi Melalui Peningkatan Ketahanan Pangan Untuk Mencegah Stunting di Desa Ilomangga Kecamatan Tolinggula Kabupaten Gorontalo Utara
}

\author{
Ansar ${ }^{1}$, Hasanuddin ${ }^{2}$ \\ ${ }^{1}$ Fakultas IImu Pendidikan, Universitas Negeri Gorontalo, Jl. Jend. Sudirman No.6, \\ Dulalowo Timur, Kota Tengah, Kota Gorontalo, Gorontalo 96128, Indonesia \\ ${ }^{2}$ Fakultas Teknik, Universitas Negeri Gorontalo, Jl. Jend. Sudirman No.6, Dulalowo \\ Timur, Kota Tengah, Kota Gorontalo, Gorontalo 96128, Indonesia \\ email: ansar@ung.ac.id, hasanuddin@ung.ac.id
}

\begin{abstract}
Abstrak
Stunting adalah terjadinya kekurangan gizi secara kronis apalagi saat pandemi covid 19 membuat adanya kekwatiran masyarakat akan beraktifitas lebih jauh atau berkeliaran dalam memenuhi kebutuhan pokoknya, maka dari itu perlunya pencegahan stunting sedini mungkin melalui ketahanan pangan dengan melihat potensi lokal daerah dengan menerapkan bioekonomi. Bioekonomi merupakan suatu sistem ekonomi dalam pengelolaan dan pengolahan sumber daya alam, yaitu pemanfaatan secara biologi dan ekonomi untuk pemenuhan kebutuhan dasar masyarakat. Untuk menunjang hal tersebut, maka pada pengabdian ini akan dilakukan proses pengolahan dan pengelolaan dengan memanfaatkan lahan pekarangan sebagai media tanam hortikultura. Metode ini secara sistematis dilakukan untuk meningkatkan nilai gizi pada tanaman hortikultura dimana menggunakan pupuk organik sehingga aman untuk dikonsumsi terutama bagi ibu - ibu rumah tangga atau ibu hamil. Pencengahan stunting dapat dilakukan. Kemudian juga pemanfaatan lahan pekarangan dan pupuk organik yang diolah sendiri oleh masyarakat melalui pendampingan mahasiswa diharapkan akan mengurangi biaya pupuk dan juga masyarakat tidak banyak bepergian hanya untuk belanja keperluan sehari-hari. Hasil kegiatan yaitu tersosialisasi Pencegahan Stunting. Program sosialisasi Pencegahan Stunting ini merupakan salah satu program inti mahasiswa KKN yang dilatar belakangi oleh masalah stunting nasional dengan pemaparan materi singkat, sesi tanya jawab, dan pembagian leaflet kesehatan mengenai pencegahan stunting.Tujuan dari kegiatan ini diharapkanmasyarakat dapat mengetahui dan melakukan pencegahan sedini mungkin mengenai stunting yang sekarang termasuk dalam kelompok penyakit tidak menular (PTM) dengan prevalensi cukup tinggi di Indonesia.
\end{abstract}

Kata Kunci: Stunting, edukasi, pelatihan, kewirausahaan, hortikultura

\section{Abstract}

Stunting is the occurrence of chronic malnutrition, especially when the COVID-19 pandemic has made people worry about further activities or wandering about fulfilling their basic needs, therefore it is necessary to prevent stunting as early as possible through food security by observing the local potential of the region by applying bioeconomics. Bioeconomics is an economic system in the management and processing of natural resources, namely biological and economic use to fulfill the basic 
needs of society. To support this, processing and management processes will be carried out in this service by utilizing the yard as a horticultural planting medium. This method is systematically carried out to increase the nutritional value of horticultural crops by using organic fertilizers so that it is safe for consumption, especially for housewives or pregnant women. Stunting mediation can be done. Then also the use of yard land and organic fertilizers which the community processes themselves through student mentoring is expected to reduce the cost of fertilizers and also that the community does not travel a lot just to shop for daily necessities. The result of the activity was socializing the prevention of stunting. This Stunting Prevention socialization program is one of the core programs of KKN students which is motivated by the national stunting problem with material exposure, question and answer sessions, and distribution of health leaflets on stunting prevention and training on horticultural processing as nutritious food. The aim of this activity is that the community is expected to know and take precautions as early as possible regarding stunting, which is now included in the non-communicable disease group with a high enough prevalence.

Keywords; Stunting; education; training; entrepreneurship; horticulture

(C) 2021 Ansar, Hasanuddin Under the license CC BY-SA 4.0

Correspondence author: Ansar, ansar@ung.ac.id, Gorontalo, and Indonesia

\section{PENDAHULUAN}

Stunting merupakan suatu permasalahan terhambatnya pertumbuhan manusia mulai saat bayi dalam kandungan diakibatkan oleh kekurangan gizi kronis sehingga mengalami usia pendek, Laporan UNICEF tahun 2010, beberapa fakta terkait stunting dan pengaruhnya adalah sebagai berikut : a. Anak yang mengalami stunting lebih awal yaitu sebelum usia enam bulan, akan mengalami stunting lebih berat menjelang usia dua tahun. Stunting yang parah pada anak, akan terjadi defisit jangka panjang dalam perkembangan fisik dan mental sehingga tidak mampu untuk belajar secara optimal di sekolah dibandingkan anak dengan tinggi badan normal.

Permasalahan utama pada stunting adalah terjadinya kekurangan gizi secara kronis apalagi saat pandemi covid 19 membuat adanya kekwatiran masyarakat akan beraktifitas lebih jauh 
atau berkeliaran dalam memenuhi kebutuhan pokoknya, maka dari itu perlunya pencengahan stunting sedini mungkin melalui ketahanan pangan dengan melihat potensi lokal daerah dengan menerapkan bioekonomi.

Bioekonomi merupakan suatu sistem ekonomi dalam pengelolaan dan pengolahan sumber daya alam, yaitu pemanfaatan secara biologi dan ekonomi untuk pemenuhan kebutuhan dasar masyarakat. Untuk menunjang hal tersebut, maka pada pengabdian ini akan dilakukan proses pengolahan dan pengelolaan dengan memanfaatkan lahan pekarangan sebagai media tanam hortikultura.

Metode ini secara sistematis dilakukan untuk meningkatkan nilai gizi pada tanaman hortikultura dimana menggunakan pupuk organik sehingga aman untuk dikonsumsi terutama bagi ibu - ibu rumah tangga atau ibu hamil. Pencengahan stunting dapat dilakukan. Kemudian juga pemanfaatan lahan pekarangan dan pupuk organik yang diolah sendiri oleh masyarakat melalui pendampingan mahasiswa diharapkan akan mengurangi biaya pupuk dan juga masyarakat tidak banyak bepergian hanya untuk belanja keperluan sehari -hari.

Adanya ilmu pengetahuan dan teknologi metode bioekonomi yang diterapkan di masyarakat melalui pendampingan mahasiswa diharapkan memberikan dampak pada pencengahan stunting dimasa pandemi covid 19.

\section{METODE PELAKSANAAN}

Metode pelaksanaan ini menggunakan model perubahan dengan pendekatan partisipasi aktif melalui pemberdayaan pendampingan masyarakat dengan sentuhan teknologi pembelajaran melihat dari 
perilaku, kondisi kehidupan desa yang diperankan oleh mahasiswa, aparat pemerintah desa dan masyarakat.

Menurut Yunasaf, U. dan Darwis, R.S. model perubahan secara teoritis digunakan seperti Model reformasi dari Niehoff, yang beranjak dari adanya gagasan atau rencana yang diperkenalkan oleh pembawa inovasi kepada warga masyarakat, sehingga dari interaksi tersebut akan terjadi integrasi baru. dan Model orientasi proses dari Batten, yang menekankan pentingnya perubahan sikap dan tingkah laku, yang pada gilirannya menggugah partisipasi warga masyarakat untuk melaksanakan pembaharuan. Perubahan sikap dan tingkah laku dihasilkan oleh proses pendidikan dan pengorganisasian sebagai hasil komunikasi dan kerjasama pekerja agen perubah dengan warga masyarakat itu sendiri.

Tahapan - tahapan kegiatan diuraikan seperti berikut :

a. Program sosilisasi

Kegiatan sosilisasi dilakukan oleh mahasiswa untuk memberikan informasi kepada masyarakat tentang keberadaan mahasiswa, program kerja, dan keinginan masyarakat akan keberadaan mahasiswa.

\section{b. Program Edukasi}

Kegiatan edukasi dilakukan untuk memberikan informasi ilmu pengetahuan dan teknologi tentang tujuan, proses, kegiatan yang akan dilaksanakan oleh mahasiswa berdasarkan tema KKN yang diusung melalui FGD, pelatihan. 
c. Program Kolaborasi

Ketercapaian program dapat terlaksana apabila pelaksanaan kegiatan KKN melibatkan berbagai unsur atau kolaborasi antara masyarakat penerima manfaat, Aparat Desa dan Mahasiswa.

\section{HASIL DAN PEMBAHASAN}

\section{Hasil}

Kegiatan KKN Tematik berdasarkan tema dengan metode dan tahapan - tahapan secara keseluruhan berjalan sesuai rencana di Desa Ilomangga Kec. Tolinggula Kab. Gorontalo Utara. Terlihat antusiasnya masyarakat akan keberadaan mahasiswa dan berkolaborasi dalam menyukseskan program kerja. Adanya pengetahuan ilmu dan teknologi yang diperoleh oleh masyarakat dapat mendorong pemahaman tentang ketermanfaatan sumberdaya lokal dalam mencegah bahaya stunting.

\section{Pembahasan}

Stunting adalah kondisi gagal tumbuh pada tubuh dan otak akibat kekurangan gizi dalam waktu yang lama. Sehingga, anak lebih pendek dari anak normal seusianya dan memiliki keterlambatan dalam berpikir. Stunting masuk dalam kelompok penyakit tidak menular yang disebabkan oleh kurangnya asupan gizi yang diterima janin atau bayi, sanitasi yang kurang baik, kemampuan ekonomi yang kurang, tingkat kesadaran masyarakat yang masih rendah dan pola hidup serta budaya masyarakat.

Sebagai upaya menurunkan prevalensi stunting di Gorontalo, lebih tepatnya di Kabupaten Gorontalo Utara maka mahasiswa KKN Tematik UNG Desa llomangga Kecamatan Tolinggula menyelenggarakan kegiatan Sosialisasi Pencegahan Stunting. Program sosialisasi 
Pencegahan Stunting ini merupakan salah satu program inti mahasiswa KKN yang dilatar belakangi oleh masalah stunting nasional.

Kegiatan ini dilaksanakan di Kantor Desa llomangga dirangkaikan dengan kegiatan POSYANDU yang dilaksanakan oleh kader kesehatan Desa llomangga. Sosialisasi ini dilakukan dengan pemaparan materi singkat, sesi tanya jawab, dan pembagian leaflet kesehatan mengenai pencegahan stunting.

Tujuan dari kegiatan ini diharapkan masyarakat dapat mengetahui dan melakukan pencegahan sedini mungkin mengenai stunting yang sekarang termasuk dalam kelompok penyakit tidak menular (PTM) dengan prevalensi cukup tinggi di Indonesia


Foto Pemaparan Materi Sosialisasi Kepada Masyarakat dan

Sesuai dengan tema Kuliah Kerja Nyata (KKN) Tematik UNG di Desa llomangga tahun 2020 yaitu "Pemanfaatan Potensi Desa Berbasis Bioekonomi Melalui Peningkatan Ketahanan Pangan Untuk Mencegah Stunting" maka mahasiswa KKN merencanakan upaya pemanfatan potensi desa berbasis bioekonomi direalisasikan dengan pembuatan green house dan akan ditanami oleh sayur-sayuran yang tinggi akan kandungan vitamin dan kalsium untuk mencegah stunting. 
Hasil panen dari green house tersebut direncanakan diolah untuk dibuat produk sehingga segi bioekonomi dapat tercapai.

Proses pembuatan dan pengembagan green house dilakukan mahasiswa dan bekerjasama dengan masyarakat Desa llomangga. Bibit tanaman yang digunakan sebagian berasal dari pemberian warga dan sebagian berasal dari mahasiswa. Rencana awal setelah sayuran di green house ini tumbuh adalah pembuatan olahan makanan yang menarik dari sayuran sehingga mampu menarik minat dari anak-anak untuk mengonsumsi sayuran.

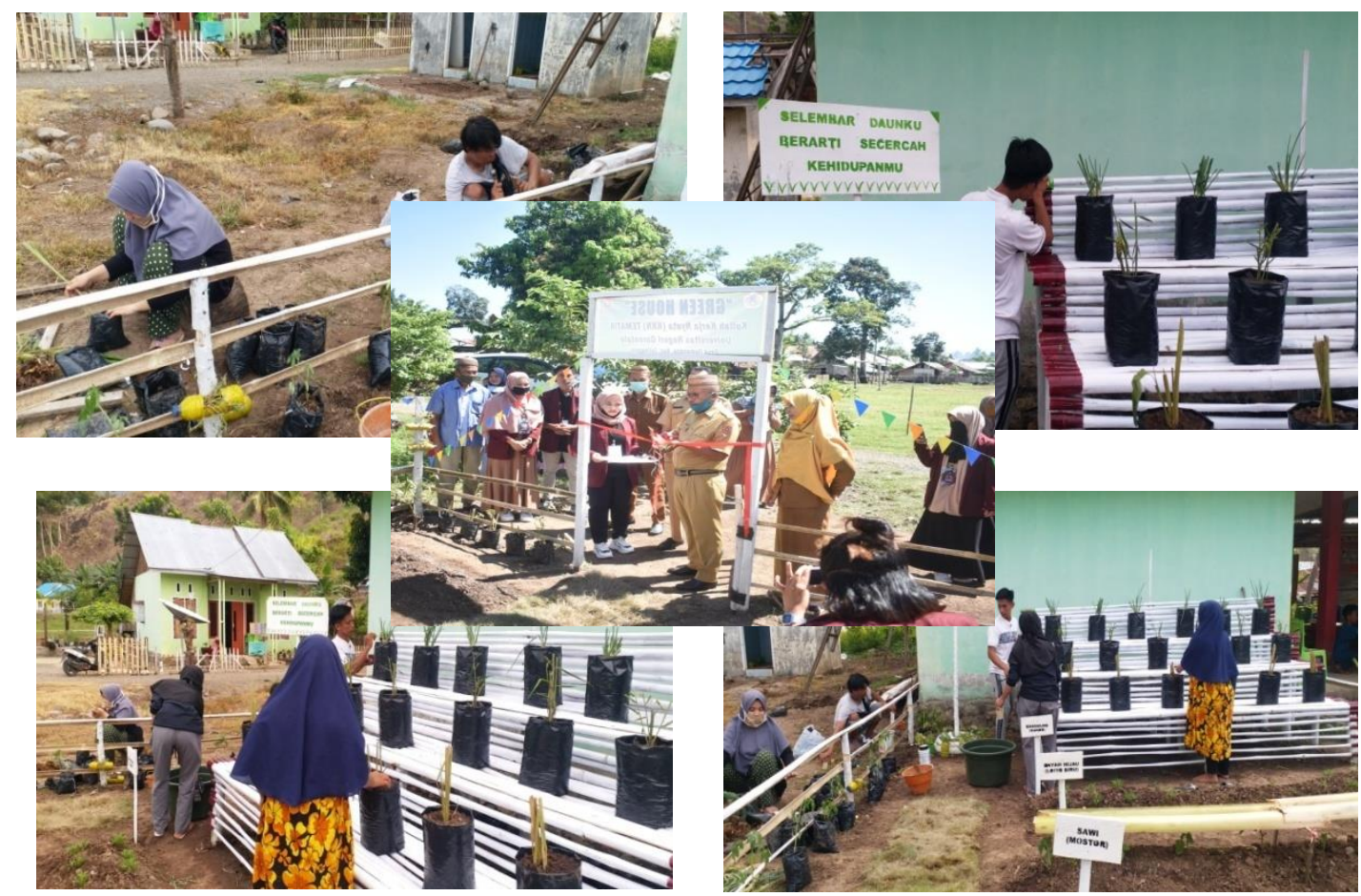

Foto Pembuatan Green House dan persmian oleh Camat Tolinggula

KKN Tematik mengadakan pembuatan keripik bayam untuk mengembangkan potensi desa dari segi biekonomi. Olahan keripik bayam ini diharapkan mampu mengembangkan minat mengonsumsi 
sayuran serta menjadi ide usaha kreatif yang dapat dikembangkan di Desa llomangga.


Foto Olahan Keripik Bayam

\section{KESIMPULAN}

Adanya program kerja mahasiswa KKN memberikan peningkatan nuansa ilmu pengetahuan dan teknologi kepada masyarakat seperti :

1. Pengetahuan stunting dan bahayanya

2. Potensi Desa yang dimanfaatkan secara optimal untuk mencegah stunting

3. Pemanfaatan lapak untuk komoditi hortikultura

4. Peluang Usaha Hortikultura

\section{UCAPAN TERIMA KASIH}

Terima kasih kepada Lembaga Penelitian dan Pengabdian pada Masyarakat (LPPM), Universitas Negeri Gorontalo atas dukungan Dana Pengabdian PNBP 2020 


\section{DAFTAR PUSTAKA}

Kerangka Acuan Kegiatan, 2020. KKN Tematik Anggaran tahun 2020.

Lembaga Penelitian dan Pengabdian Pada Masyarakat Universitas Negeri Gorontalo

Yunasaf, U. dan Darwis, R.S. 2020 Materi Wawasan Sosial Kemasyarakatan dan Pendekatan Sosial Dalam KKNM-PPMD Integratif Unpad. Di akses tgl 5 november 2020 